\title{
ŁAMANIE PRAW CZLOWIEKA W KOREAŃSKIEJ REPUBLICE LUDOWO-DEMOKRATYCZNEJ
}

Problematyka praw człowieka w Korei Północnej zasługuje na szczególną uwagę. Ludzie są tam poddawani bezustannej inwigilacji w każdej dziedzinie życia. Dominującym tematem, który pojawia się w związku z Koreańską Republiką Ludowo-Demokratyczną jest zagrożenie nuklearne - problem niewątpliwie wielkiej wagi, jednak oczy światowej polityki nie zwracają się w stronę równie istotnego proble$\mathrm{mu}$ - dramatu zwykłych ludzi, jakim jest notorycznie łamanie praw człowieka.

Celem artykułu jest ukazanie metod, jakimi posługuje się reżim panujący w KRLD w stosunku do swoich obywateli. Wskazano na możliwość pociagnięcia do odpowiedzialności karnej przed kompetentnym organem międzynarodowym Kim Dzong Una i jego podwładnych odpowiedzialnych za sytuację w północnej części Półwyspu Koreańskiego. W tym celu przedstawiono system północnokoreańskich obozów pracy i zwrócono uwagę na panujące tam warunki, które są dalekie od wszelkich standardów praw człowieka. Co więcej, metody, jakimi posługuje się reżim, wpisują się w definicję zbrodni przeciwko ludzkości.

Koreańska Republika Ludowo-Demokratyczna jest jednym z najbardziej tajemniczych i zamkniętych krajów świata. W literaturze pojawiają się takie określenia, jak: kraj Zombie ${ }^{1}$, „społeczeństwo bez przyszłości i bez nadziei”2 czy „kraj cichej śmierci”’. Państwo to karmi swoich obywateli nieustanną propaganda, bezlitośnie rozprawia się z przeciwnikami politycznymi, a światową opinię publiczną zastrasza groźbą użycia broni nuklearnej. To fenomen w skali międzynarodowej, miejsce, w którym zmarli cieszą się większymi przywilejami aniżeli zwykli mieszkańcy Półwyspu Koreańskiego ${ }^{4}$. Uwzględniając odmienności światopoglądowe i kulturowe

1 Określenie zostało użyte przez J. Sweeney w książce: Korea Pótnocna. Tajna misja w kraju wielkiego blefu, Warszawa 2015.

2 K. Chul-hwan, A. Hyok, Džieci w pótnocnokoreańskich obozach [w:] Korea Pótnocna za zastona, red. A. Rzepliński, J. Hosaniak, tłum. J. Hosaniak, Warszawa 2004, s. 33.

3 Termin zaczerpnięty z filmu dokumentalnego Na osi z̧ła-kraj cichej śmierci (reż. E. Ewart), wyprodukowanego dla BBC w 2004 r.

4 Przykładem takiej dysproporcji jest brak stałych dostaw energii elektrycznej w tak newralgicznych miejscach, jak szpitale czy szkoły, przy czym w mauzoleum Kim Dzong Ila i Kim Ir Sena jest ona zapewniona przez 24 godziny na dobę. Trzeba jednak zwrócić uwagę na bardzo istotny kult przodków zakorzeniony głęboko w kulturze Azji Wschodniej. 
pomiędzy cywilizacją Wschodu i Zachodu, nie sposób jednak zrozumieć naruszeń praw człowieka w tym kraju. Warto bowiem zauważyć, że na terytorium KRLD nie funkcjonuje żadna opozycja polityczna, co jest właściwie ewenementem w skali międzynarodowej, a jakiekolwiek przejawy nieposłuszeństwa w stosunku do panującej dyktatury są surowo karane.

Największą bolączką systemu jest głód, często wykorzystywany jako narzędzie kontroli i walki z ewentualnymi politycznymi oponentami ${ }^{5}$. Wielka fala głodu, która osiagnęła apogeum w połowie lat 90., przypominała rozmiarami hołodomor 6 i pochłonęła tysiące istnień ludzkich. W raporcie przedstawionym podczas drugiej sesji IV Konferencji „North Korean Human Rights and Refugees” H. Maass zauważa, że dzieci, które straciły rodziców w czasie wielkiego głodu w latach 19951997, wędrują po kraju, żebrząc o pożywienie, a władze Korei, zamiast udzielić im pomocy, organizują specjalne miejsca dla sierot, gdzie czeka je niemal pewna śmierć głodowa, bo pożywienie nie jest praktycznie dostarczane ${ }^{7}$. Korea Północna jest jednym z największych na świecie beneficjentów pomocy żywnościowej. Głód jednak ma podłoże polityczne i jest wykorzystywany jako narzędzie systemowej walki z oportunistami ${ }^{8}$. Dodatkowym problemem jest fakt, że władze KRLD nie pozwalaja organizacjom humanitarnym na swobodne przemieszczanie się po kraju i dotarcie z pomocą do najbardziej potrzebujacych; w związku z tym nie ma pewności, czy dostarczana pomoc dociera do najbiedniejszych, a nie jest rozdzielana przez wojsko i partyjnych prominentów ${ }^{9}$.

Reżim dysponuje całym wachlarzem spektakularnych środków represji stosowanych przeciwko oponentom politycznym: od publicznej samokrytyki poczynając, poprzez instytucję przymusowych rozwodów ${ }^{10}$, pobyt w przymusowym w obozie pracy, na karze śmierci kończąc. Rozbudowany aparat represji ingeruje w każdą sferę życia mieszkańców KRLD, sięgając często granic absurdu, który jest nie do pojęcia dla przeciętnego Europejczyka ${ }^{11}$. Znamiennym przykładem są liczne doniesienia

5 Zob. United Nations, The price is rights: The violation of the right to an adequate standard of living in the Democratic People's Republic of Korea, Seoul 2019.

${ }^{6}$ Klęska wielkiego głodu w ZSRR w latach 1932-1933 pochłonęła ok. 6-7 mln ludzi.

7 K. Chul-hwan, A. Hyok, Drieci..., s. 126.

8 M. O'Doherty, The legacy of Kim Jong-un and the worker's party in North Korea. A one-party state facilitating militarism, nuclear armament and dsiregard for human rights, Midrand 2017, s. 35.

9 Ibidem, s. 127, 128.

10 Rozporządzeniem nr 24 z 8 marca 1956 r. zniesiono instytucję rozwodów za obopólną zgodą i wprowadzono zasadę, że o rozwodzie będzie orzekał sąd (H. Ogawa, Pochwała ca̧y potępienie sytuacja kobiet w Korei Pótnocnej [w:] Korea Pótnocna za zastonq..., s. 88). Instytucja przymusowych rozwodów jest zakazana w prawie międzynarodowym. W Korei Północnej jest to natomiast często stosowany instrument, który stosuje się pod pretekstem oszczędzenia życia żonie więźnia. K. Chul-hwan, A. Hyok, Drieci..., s. 29.

11 Z doniesień prasowych wynika, że po objęciu władzy przez Kim Dzong Una dyktator dokonał ścisłej reglamentacji fryzur, które mogli nosić jego poddani. Kobiety mogły wybierać spośród 
prasowe i medialne informujące jeszcze nie tak dawno o rozhisteryzowanych tłumach po śmierci Ojca Narodu ${ }^{12}$ - Kim Dzong Ila, co zakrawa na groteskę, wydaje się bowiem wyreżyserowanym przedstawieniem, a nie szczerze wyrażanym żalem po śmierci uwielbianego przywódcy. Trudno się jednak dziwić takiemu stanowi rzeczy, ponieważ Koreańczycy z KRLD od najmłodszych lat są poddawani indoktrynacji, a każde najmniejsze przewinienie, każdy wyraz nieposłuszeństwa czy niezadowolenia jest bezlitośnie karany bez względu na pozycję społeczną, pochodzenie czy wykształcenie. W tym tłumie nie ma miejsca na indywidualizm ani jakąkolwiek krytykę, wszyscy stanowią jedną zwartą masę, która ma tylko jeden cel - bezwzględne posłuszeństwo Niezłomnemu Przywódcy Partii, Państwa i Armii - Kim Dzong Unowi. W przeciwnym wypadku niepokorna jednostka zostanie zmiażdżona i skutecznie wyeliminowana.

\section{Obozy pracy}

Korea Północna pozostaje oficjalnie państwem ateistycznym, ale gwarantującym wolność religii w przepisach konstytucyjnych. Osoby, które ją otwarcie manifestuja, spotykają się jednak z represjami ${ }^{13}$. Szczególnie narażoną grupą są chrześcijanie, a Korea Północna od lat zajmuje haniebne pierwsze miejsce wśród państw prześladujących wyznawców tej religii. Duża ich część zasila szeregi więźniów obozów pracy, a publiczne noszenie Biblii jest zakazane. Szacuje się, że co najmniej jedna czwarta północnokoreańskich chrześcijan była więźniami obozów pracy ${ }^{14}$. Mark O’Doherty podaje, że liczba osadzonych za wiarę w przymusowych obozach pracy waha się w granicach od 50 tys. do 70 tys. $^{15}$

osiemnastu zaproponowanych uczesań, mężczyźni natomiast dostali do wyboru katalog dziesięciu dopuszczalnych fryzur. W 2014 r. natomiast wszyscy północnokoreańscy studenci dostali odgórny nakaz ostrzyżenia się „na Kim Dzong Una”. Przez długi czas północnokoreańska telewizja prowadziła wojnę z mężczyznami noszącymi długie włosy, co było w oczach reżimu przyjmowaniem niedopuszczalnych zachodnich wzorców, zob. Pótnocnokoreańscy studenci muszq sie ostrazyc „na Kim Díong Una, „Gazeta Wyborcza”, 26.03.2014, http://wyborcza.pl/1,76842,15692339,Polnocnokoreanscy_studenci_musza_sie_ostrzyc_na_Kim.html (dostęp: 8.02.2017); także: A. Ploetzing, Tożsamość Koreańcayyków z Pótnocy - uwagi wstępne, „Gdańskie Studia Azji Wschodniej” 2013, z. 4, s. 145.

12 Jeden z oficjalnych tytułów przyznanych Kim Dzong Ilowi.

13 M. O'Doherty, The legacy of Kim Jong-un..., s. 20.

14 Persecution of Christians in North Korea, https://www.christianvoice.org.uk/wp-content/uploads/2012/02/Persecution-of-Christians-in-North-Korea.pdf (dostęp: 20.12.2019); M. Rees, World Watch List Report 2018, The Open Doors 2018; G.J. Marlin, S. Boghjalian, Persecuted and forgotten. A report on Christians oppressed for their faith 2015-17. Executive Summary, Aid to the Church in Need, New York [b.d.], s. 5, https://www.churchinneed.org/wp-content/uploads/2017/10/ persecution-1-1.pdf (dostęp: 18.12.2019).

15 M. O’Doherty, The legacy of Kim Jong-un..., s. 21. 
Choć oficjalnie Korea Północna zaprzecza funkcjonowaniu na terytorium kraju takich miejsc ${ }^{16}$, pozostają one smutnym faktem. Niezaprzeczalnym dowodem na istnienie obozów pracy przymusowej są zdjęcia satelitarne dostarczane przez organizacje pozarządowe oraz relacje uciekinierów, którym udało się z tej machiny śmierci ujść z życiem ${ }^{17}$. Nie do końca wiadomo, ile jest obozów pracy przymusowej zlokalizowanych na terytorium KRLD - w zależności od źródeł ich liczbę szacuje się od czterech do siedmiu ${ }^{18}$. Jednak niepodważalnym faktem jest ich istnienie. Obozy zostały utworzone na skutek rozporządzenia w sprawie wprowadzenia pracy przymusowej. Z dokumentacji resortów spraw wewnętrznych i sprawiedliwości z dnia 30 października 1947 r. wynika, że w tamtym okresie na terytorium Korei Północnej funkcjonowało siedemnaście takich miejsc ${ }^{19}$.

System północnokoreańskich obozów można podzielić na dwa typy: tzw. Gwaliso ${ }^{20}$, oznaczające w języku koreańskim „miejsce zarządzania”, przeznaczone dla więźniów politycznych, w którym przeprowadza się eksperymenty na ludziach ${ }^{21}$. Na pobyt $\mathrm{w}$ takim obozie może zostać zesłana cała rodzina, zgodnie z zasada mówiącą o tym, że wrogów reżimu należy karać do trzeciego pokolenia włącznie, co wiąże się ze wspomnianą już odpowiedzialnością zbiorową ${ }^{22}$. W państwach Azji Wschodniej interesy zbiorowe stoja na pierwszym miejscu, co jest zgodne

16 Istnienie obozów pracy jest tajemnicą na skutek rozporządzeń Kim Ir Sena i Kim Dzong Ila. Zob. H. Ogawa, Wspótzależność pomiedży ideologia Dizucze a obozami dla wieźnión politycznych w Korei Pótnocnej [w:] Korea Pótnocna za zastonq..., s. 73.

17 Organizacja pozarządowa Amnesty International opublikowała raport potwierdzający istnienie północnokoreańskich obozów pracy, posługując się w tym celu zdjęciami satelitarnymi Amnesty International, North Korea New Satellite images show continued investment in the infrastructure of repression, London 2013; więcej na ten temat w książce Korea Pótnocna za zasłonq...

18 Według raportu ONZ będącego wynikiem pracy specjalnej komisji powołanej do zbadania sytuacji praw człowieka w Korei Północnej: Obóz nr 14 ma 150 km² i mieści się niedaleko miasta Kaechon, w prowincji Pyongan Południowy. Do tej pory wiadomo, że uciekł z niego tylko jeden więzień - Shin Dong Hyuk. Obóz nr 15 ma 370 km² i znajduje się w rejonie Yodok, w prowincji Hamgyong Południowy i Pyngoan Południowy. Obóz nr 16 obejmuje ok. $560 \mathrm{~km}^{2}$ na surowym terenie w Myonggan, w prowincji Hamgyong Północny. Obóz nr 25 mieści się również w prowincji Hamgyong Północny, ale w rejonie miasta Chongjin. W ostatnich latach został powiększony i obecnie uważany jest za największy - ma $980 \mathrm{~km}^{2}$, http://www.tvn24.pl/wiadomosci-ze-swiata, 2/onz-udowodnil-zbrodnie-korei-szanse-na-ukaranie-kima-zadne,400585.html (dostęp: 15.02.2017). H. Ogawa, Wspótzależność..., s. 73.

19 Ibidem, s. 74.

20 Określane też jako: gwalliso lub kwan-li-so.

21 B. Demick, Notbing to envy. Real lives in North Korea, London 2010, s. 174.

${ }^{22}$ W 2013 r. na terytorium KRLD było sześć obozów typu Kwan-li so; D. Hawk, The Hidden Gulag. Second Edition. The Lives and Voices of "Those Who are Sent to the Mountains". Exposing North Korea's Vast System of Lawless Imprisonment. A Report by the Committee for Human Rights in North Korea, Washington 2012, s. 9; zob. też: http://www.tvn24.pl/wiadomosci-ze-swiata,2/korea-polnocna-pieklo-z-ktorego-mozna-uciec-tylko-za-pieniadze,361807.html (dostęp: 15.11.2019). 
z założeniami konfucjonizmu i jak zauważa K. Gawlikowski, jednostkę interpretuje się ,„jako cząstkę kolektywu, nie zaś jako autonomiczny podmiot, co odzwierciedla odmienną od zachodniej tradycję filozoficzno-kulturową, której obce było indywidualistyczne i personalistyczne ujęcie człowieka"23.

Obozy przeznaczone dla więźniów politycznych to obozy ostateczne. Z nich nie wychodzi się żywym. Ludzie tam zesłani często nie doczekali procesu, a ci, którym było to dane, zostali skazani w procesach pokazowych ${ }^{24}$. Więźniowie są poddawani niewyobrażalnym torturom, ponadto przeprowadza się na nich doświadczenia. John Sweeney gorzko zauważa, że w przypadku tego obozu większość trafiających tam ludzi w innym państwie nie zostałaby nigdy uznana za przestępców ${ }^{25}$. Podobnie D. Hawk pisze, że czyny, za których popełnienie można zostać osadzonym w Gwaliso, to „crimes that are not really crimes”26. Osadzeni są oskarżeni o spiskowanie przeciwko panującej dyktaturze, złe myślenie czy niewłaściwe pochodzenie, a nawet za obracanie się w podejrzanym środowisku. Więźniem politycznym może zostać właściwie każdy, kto jest podejrzany o jakąkolwiek nielojalność w stosunku do władzy. W obozie tego typu znajdują się specjalnie wydzielone strefy: osobna dla mężczyzn, osobna dla kobiet, wspólna dla rodzin ${ }^{27}$. Jak podaje P. Rigoulot, „strażnicy (...) zwykli powtarzać: »Istnieją tylko dwa lekarstwa na wyplenienie wpływów zepsutej ideologii kapitalistycznej: praca i kontrola«"28.

Innym miejscem jest Gyohwaso (lub Kyo-Hwa-So), gdzie „robi się dobrego człowieka" poprzez jego reedukację. To obóz długoterminowy, w którym także przeprowadza się eksperymenty na ludziach, przeznaczony zarówno dla zwykłych kryminalistów, jak i więźniów politycznych. To obóz terminowy o bardzo zaostrzonym rygorze i złych warunkach ${ }^{29}$. Ponadto funkcjonują: Ku-Ryu-Jang (lub guryujang) - tzw. izba przesłuchań, które przeprowadza tajna policja Bowibu i agencja policji kryminalnej An-jeon-bu; Jip-Kyul-So (lub jüpkyulso) - krótkoterminowe miejsce pracy karnej i zatrzymań, przeznaczone dla zwyczajnych kryminalistów oraz więźniów politycznych; Ro-dong-dan-ryon-dae (lub nodongdanryeondae) - miejsce pracy i szkoleń, gdzie funkcjonują tzw. mobilne brygady pracy oraz więzienie Ka-mok (lub gamok) $)^{30}$. Dokładna liczba osób przebywających w obozach jest trudna

${ }^{23}$ K. Gawlikowski, Pojmowanie jednostki w tradycji konfucjańskiej i jego konsekwencje dla sycia politycznego w Azji Wschodniej, https://www.swps.pl/images/stories/dokumenty/ccaw/29-Jednostka-w-tradycji-konfucjanskiej.pdf (dostęp: 20.12.2019).

24 Ibidem.

25 J. Sweeney, Korea Pótnocna..., s. 359.

26 D. Hawk, The Hidden Gulag..., s. 25.

27 Ibidem.

28 P. Rigoulot, Analiza porównawcza obozón koncentracyjnych w nazistowskich Niemczech, Zwiazku Radrieckim i Korei Pótnocnej [w:] Korea Pótnocna za zastonq..., s. 55.

29 D. Hawk, The Hidden Gulag..., s. 10.

30 Ibidem, s. 22; także film dokumentalny Yodok stories, reż. A. Fidyk, Norwega-Polska 2008. 
do oszacowania. Organizacja Human Rights Watch podaje, że łącznie w obozach przebywa od 80 tys. do 120 tys. ludzi ${ }^{31}$.

Przerażający obraz przymusowych obozów pracy po raz pierwszy ujrzał światło dzienne dzięki relacjom Sehora Aliego Lamedy, wenezuelskiego poety, pierwszego zachodniego więźnia skazanego na pobyt w północnokoreańskim obozie pracy. Był on więziony w obozie Sariwon w 1967 r. Jego wspomnienia zostały opublikowane przez Amnesty International w celu zwrócenia uwagi światowej opinii publicznej na łamanie praw człowieka w KRLD ${ }^{32}$. Z relacji A. Lamedy wyłania się obraz nieustannego głodu, osamotnienia i warunków uragających wszelkim podstawowym potrzebom człowieka. Dzienny przydział jedzenia nie wynosił więcej niż 300 g, więźniowie nie zmieniali swoich ubrań, a warunki sanitarne, a właściwie ich brak, stanowiły smutną rzeczywistość. Cele, w których więźniowie odbywali swoje kary, były małe i przeludnione. Dodatkową bolączką był brak jakiejkolwiek opieki medycznej oraz leków ${ }^{33}$. Te informacje zostały potwierdzone przez innych więźniów, w tym przez Lee Baek-lyong, który był więźniem politycznym w połowie lat 90 . Według jego relacji: „Jedzenie podawano w małych dawkach 33 gramy ryżu i zupy z kapusty na jeden posiłek. (...) Któregoś razu postanowiono mnie głodzić. Dawali mi dwa posiłki dziennie. W rezultacie straciłem $40 \mathrm{~kg}$. Ważyłem $94 \mathrm{~kg}$ z początku, a na koniec $54 \mathrm{~kg}$. Jedyną rzecza, która pozwalała mi przetrwać, była ogromna wola życia. To było wszystko, co miałem" ${ }^{\prime 3}$.

\section{Różnice i podobieństwa pomiędzy obozami północnokoreańskimi a obozami funkcjonującymi w czasie II wojny światowej}

Mechanizmy stosowane w północnokoreańskich obozach pracy niczym nie odbiegają od metod, jakimi posługiwali się naziści w czasie II wojny światowej. Pierre Rigoulot zwraca uwagę na podobieństwo północnokoreańskich obozów pracy do obozów hitlerowskich i sowieckich, słusznie przy tym zauważając, że są one często nieodzownym elementem systemu totalitarnego, na który składają się: jedna, narzucona ideologia, dyktatura jednopartyjna, Führerprinzip, wchłonięcie społeczeństwa obywatelskiego przez sektor polityczny i - najważniejsze - stały system obozów. Ponadto autor wskazuje takie podobieństwa, jak umieszczanie ludzi w obozach

31 Human Rights Watch 2017: https://www.hrw.org/sites/default/files/northkorea_2.pdf (dostęp: 20.12.2019).

32 A. Lameda, A personal account of the experience of a Prisoner Conscience in the Democratic People's Republic of Korea, International Secretariat, Amnesty International 1979.

33 Ibidem, s. 13, 14 i nn.

34 L. Baek-lyong, Bytem wię̧niem obozu dla wię́niów politycznych w Korei Pótnocnej [w:] Korea Pótnocna za zastona..., s. 18. 
pracy bez wyroku sądowego oraz nieudzielanie im informacji dotyczących długości wymierzonej kary ${ }^{35}$.

Analogiczne porównania czyni D. Hawk, zestawiając północnokoreańskie obozy pracy z gułagami ZSRR, zaznacza jednak, że warunki panujące w północnokoreańskich obozach pracy są o wiele gorsze. Autor wskazuje również różnice w traktowaniu więźniów w ZSRR w zależności od reżimu, w jakim odbywali karę. Osadzeni odbywający kary w systemie specjalnym pozbawieni byli prawa do jakichkolwiek kontaktów zewnętrznych, ale już ci, którzy swoją karę odbywali w innych systemach, mieli prawo do ograniczonej liczby wizyt czy korespondencji. Podobnie racje żywnościowe były zróżnicowane i uzależnione od ciężaru wykonywanej przez nich pracy. Takie standardy obce są systemowi totalitarnemu w Korei Północnej. Państwo odmawia swoim więźniom jakiegokolwiek kontaktu ze światem zewnętrznym, nie pozwalając na dostarczanie im jedzenia, ubrań, środków czystości czy leków, bez względu na powód ich przetrzymywania czy wykonywaną pracę ${ }^{36}$.

\section{Środki represji a prawa człowieka w Korei Północnej}

W Korei Północnej nadal obowiązuje kara śmierci, a samo uwięzienie w obozie pracy często jest równoznaczne ze skazaniem na śmierć. Przemawiają za tym wspomniane już, uragające wszelkim standardom warunki życia, stosowanie tortur, brak podstawowych warunków zapewniających higienę, a przede wszystkim nieustanny głód.

Przestępstwa w Korei Północnej można podzielić na dwie kategorie: zwykłe przestępstwa kryminalne i przestępstwa natury politycznej. Różnica między nimi polega na motywacji, w wyniku której sprawcy dopuszczają się ich popełnienia. Te pierwsze są popełniane z pobudek egoistycznych, nie są natomiast - w przeciwieństwie do przestępstw politycznych - skierowane przeciwko systemowi socjalistycznemu ${ }^{37}$.

Północnokoreański kodeks karny zalicza karę śmierci - obok długoterminowego i krótkoterminowego pobytu w obozach pracy - do kar głównych (art. 28) ${ }^{38}$. Kara śmierci zgodnie z przepisami kodeksu nie może być stosowana w stosunku do osób, które nie ukończyły 18. roku życia oraz w odniesieniu do kobiet w ciąży (art. 29), jednak z relacji więźniów wynika, że są to tylko nic nieznaczące paragrafy,

35 P. Rigoulot, Analiza porónnawcza..., s. 50.

36 D. Hawk, The Hidden Gulag..., s. 32.

37 K. Soo-Am, The North Korean Penal Code, Criminal Procedures, and their Actual Applications, Seoul 2006, s. $11,12$.

38 S. hyup Lee, H. Su Park, K. Eun Ha, M. Simpson Bell, L. Lee, A. Wolman, The Criminal Law of the Democratic People's Republic of Korea (2009), eng.nkhumanrights.or.kr/board/download.php?fileno...4... (dostęp: 15.11.2019). 
rzeczywistość natomiast kreuje się zupełnie inaczej. Ponadto według standardów zagwarantowanych przez kodeks karny KRLD czas pobytu w obozach pracy jest określony. W przypadku obozów długoterminowych może wynosić od roku do 15 lat (art. 30), a w przypadku obozów krótkoterminowych - od 6 miesięcy do 2 lat (art. 31). Trzeba jednak zauważyć, że większość skazanych na pobyt w obozach nigdy ich już nie opuszcza. Kodeks przewiduje cały katalog przestępstw, za których popełnienie grozi zesłanie do obozu pracy przymusowej, zaliczając do nich: spisek antypaństwowy (art. 59) ${ }^{39}$, terroryzm (art. 60), antypaństwową propagandę i agitację (art. 61), zdradę ojczyzny (art. 62). Niejasne sformułowania i brak legalnej definicji tych pojęć prowadzą do wielu nadużyć, pozwalają bowiem na nadinterpretację, przez co możliwa jest duża swoboda w rozprawianiu się z politycznymi oponentami.

Od czasu pobytu w Korei Północnej A. Lamedy niewiele się zmieniło. Warunki panujące w obozach nadal uragaja wszelkim standardom praw człowieka. David Hawk porusza przy tym kwestię naruszeń Wzorcowych Reguł Minimalnych Organizacji Narodów Zjednoczonych, dotyczących postępowania z więźniami ${ }^{40}$. Reguły ustalone w tym dokumencie są wspólne dla wszystkich kategorii więźniów, zarówno politycznych, jak i kryminalnych. W preambule zwrócono uwagę, że celem dokumentu jest poszanowanie godności więźniów i ich wartości jako istot ludzkich. Zgodnie z regułą I: „Wszyscy więźniowie traktowani będą z szacunkiem wynikającym z ich przyrodzonej godności i wartości jako istot ludzkich. Wobec żadnej osoby uwięzionej nie będą stosowane tortury ani też inne okrutne, nieludzkie lub poniżajace traktowanie albo karanie i wszyscy więźniowie będą przed nimi chronieni. Żadne okoliczności nie mogą stanowić usprawiedliwienia dla tortur oraz innego okrutnego, nieludzkiego lub poniżającego traktowania, albo karania. Przez cały czas zapewnione będzie bezpieczeństwo więźniów, dostawców usług i odwiedzających”. Reguły określają minimalne standardy postępowania $z$ więźniami, podstawowe zasady dotyczące ich klasyfikacji z uwagi na takie przymioty, jak: wiek, płeć, podstawa osadzenia, reguły odnoszące się do zapewnienia podstawowych warunków bytowych. Eksponuje zasady humanitaryzmu, praworządności, tolerancji oraz indywidualizacji ${ }^{41}$.

Korei Północnej wszelkie międzynarodowe standardy praw człowieka są obce, więźniowie są niedożywieni, jedzą trawę, węże i rośliny, pracując przy tym ponad siły -12 godzin lub więcej na dobę $e^{42}$. Władza zmierza do systematycznej eliminacji politycznych oponentów, eksterminując ich skutecznie z życia publicznego.

39 Należy sobie uświadomić, że zachowaniem antypaństwowym będzie zarówno publiczne obrażanie dyktatora, jak i najmniejsza jego krytyka w zaciszu domowym.

40 D. Hawk, The Hidden Gulag..., s. 30; też: United Nations Standard Minimum Rules for the Administration of Juvenile Justice (The Beijing Rules), adopted by General Assembly resolution 40/33 of 29 November 1985.

${ }^{41}$ K. Szalacha, Prawa osób osadzonych, s. 253, 254, www.wspia.eu/file/21423/27-SZALACHA. pdf (dostęp: 15.02.2017).

42 D. Hawk, The Hidden Gulag..., s. 32 i nn. 
Panuje powszechna zgoda odnośnie do tego, że prawa człowieka są niezbywalne i przyrodzone każdej istocie ludzkiej „niezależnie od przynależności państwowej i od jakichkolwiek cech różnicujących" ${ }^{43}$. $\mathrm{Na}$ ich treść składają się trzy tezy: każda władza jest ograniczona, każdej jednostce przysługuje sfera autonomii, do której nie ma dostępu żadna władza, każda jednostka może się domagać ochrony przysługujących jej praw. Prawa te przysługuja niepodzielnie każdemu człowiekowi - bez względu na jego rasę, płeć, religię czy przekonania polityczne ${ }^{44}$. Trzeba jednak pamiętać, że prawa człowieka stanowią dorobek kulturowy cywilizacji zachodnich. We wschodnich kulturach podkreśla się natomiast ważną rolę tzw. wartości azjatyckich. Anna Michalak słusznie zauważa, że każda dyskusja związana z przestrzeganiem praw humanitarnych, prowadzona z perspektywy zachodniej napotyka wiele problemów. Trudności te są związane z różnymi tradycjami oraz barierami kulturowymi. Etiologia tych odmienności ma swoje podłoże religijne, kulturowe i ideologiczne ${ }^{45}$.

Według A. Sena wspieranie wartości azjatyckich często wiąże się z potrzebą oparcia się zachodniej hegemonii ${ }^{46}$. Nie sposób jednak zrozumieć skali naruszeń praw jednostki w północnokoreańskim systemie nawet przy uwzględnieniu tych odmienności. Naruszenia te dotyczą bowiem każdej sfery życia: praw obywatelskich i politycznych, praw gospodarczych, społecznych i kulturalnych, ograniczeń prawa do wolności stowarzyszeń i zgromadzeń oraz praw wyborczych ${ }^{47}$. Na terytorium KRLD łamanie praw człowieka jest permanentne: tortury, praca ponad siły, dokonywanie publicznych egzekucji, gwałty ${ }^{48}$ - to tylko niektóre przykłady. Warto zwrócić uwagę, że w obozach umiera co trzeci więzień, co jest z kolei wynikiem wycieńczenia i wygłodzenia. Obozy koncentracyjne, a takimi są niewątpliwie północnokoreańskie obozy pracy, bez wątpienia „wpisują się w proces ludobójczy, gdyż umożliwiają koncentrację określonej, wyselekcjonowanej grupy ludności w jednym miejscu, co w sposób znaczący ułatwia dokonanie zbrodni na poszczególnych jej etapach" ${ }^{49}$.

${ }^{43}$ W. Zakrzewski, Podstawowe wolności, prawa i obowiqzki çtowieka i obywatela [w:] Polskie prawo konstytucyjne, red. W. Skrzydło, Lublin 2003, s. 154.

44 W. Osiatyński, Wprowadzenie do praw čłowieka, s. 1, www.hfhrpol.waw.pl/pliki/WOsiatynski_HistIFilo.pdf (dostęp: 15.09.2012).

45 A. Michalak, Przestrzeganie praw człowieka w uybranych państwach Azji postkolonialnej - aktualne problemy, „Przegląd Prawa Konstytucyjnego” 2013, nr 1(23), s. 115, 133.

46 A. Sen, Human rights and Asian values, New York 1997, s. 28.

47 K. Byung-ro, Sytuacja praw çłowieka w Korei Pótnocnej [w:] Korea Pótnocna za zastonq..., s. 99-111.

48 Amnesty International, North Korea New Satellite..., s. 6.

49 J. Markiewicz-Stanny, Obóz jako instrument ludobójstwa - analiza wybranych zagadnień, „Międzynarodowe Prawo Humanitarne” 2014, t. 5: Ludobójstwo jako źbrodnia miedżynarodowa, s. 174. 


\section{Kwestia odpowiedzialności międzynarodowej}

Jak wspomniano na wstępie, społeczność międzynarodowa zdaje się nie dostrzegać kwestii łamania praw człowieka w KRLD. Jednak stopniowo zaczyna się to zmieniać. W 2003 r. Komisja Praw Człowieka ONZ przyjęła rezolucję dotycząca łamania praw człowieka w Korei Północnej ${ }^{50}$. Był to pierwszy taki dokument od momentu przystapienia Korei Północnej i Południowej do ONZ w 1991 r. Zgodnie z treścią rezolucji wszystkie państwa członkowskie ONZ wyraziły głębokie zaniepokojenie sytuacją praw człowieka w Korei Północnej. Zwrócono uwagę na metody stosowane przez ten reżim, takie jak: tortury $\mathrm{i}$ inne nieludzkie traktowanie lub karanie, dokonywanie publicznych egzekucji, istnienie dużej liczby obozów pracy przymusowej, brak poszanowania praw osób pozbawionych wolności oraz nagminne wykorzystywanie kary śmierci (ust. 1 lit. A), brak możliwości swobodnego wyjazdu z kraju (ust. 1 lit. B), brak wolności sumienia i wyznania, brak możliwości organizowania pokojowych zgromadzeń, brak swobodnego dostępu do informacji (ust. 1 lit. C), naruszenia praw kobiet, zwłaszcza poprzez handel kobietami, zmuszanie do prostytucji, instytucja przymusowych małżeństw, wymuszanie aborcji, dzieciobójstwo (ust. 1 lit. D).

W dokumencie tym wezwano władze KRLD do powstrzymania się od represjonowania obywateli Korei Północnej, którzy przenieśli się do innych krajów, głównie ze względów humanitarnych. Nawoływano do zaprzestania traktowania ich wyjazdu jako zdrady karanej więzieniem, nieludzkim lub poniżającym traktowaniem albo śmiercią. Ponadto wezwano władze Korei Północnej do współpracy z organami ONZ w kwestii praw człowieka bez żadnych ograniczeń, uwzględniając procedury Komisji Praw Człowieka, a w szczególności wysłanie Specjalnego Sprawozdawcy ds. Wolności od Głodu, Specjalnego Sprawozdawcy ds. Tortur, Specjalnego Sprawozdawcy ds. Nietolerancji Religijnej, Grupy Roboczej ds. Arbitralnych Uwięzień oraz Grupy Roboczej ds. Przymusowych Zaginięć. Podkreślono przy tym konieczność rozwiązania w sposób przejrzysty i jasny kwestii uprowadzeń obcokrajowców i uznania międzynarodowych standardów pracy ${ }^{51}$.

Zarówno rezolucja, jak i wspomniane już zdjęcia satelitarne obozów pracy opublikowane w 2013 r. przez organizację pozarządową Amnesty International przyczyniły się do powołania w Genewie Komisji ds. Zbadania Praw Człowieka w Korei Północnej ${ }^{52}$. Niestety, powołanie komisji nie spotkało się z powszechną

50 UN Commission on Human Rights, Resolution on Situation of human rights in the DPRK, UN Doc. E/CN.4/RES/2004/13, April 15, 2004, ap.ohchr.org/documents/E/.../resolutions/ E-CN_4-RES-2004-13.d... (dostęp: 15.11.2019).

51 Ibidem; zob. też: Komisja Praw Cžtowieka ONZ - Rezolucja [w:] Korea Pótnocna za zastonq..., s. 147.

52 http://www.tvn24.pl/wiadomosci-ze-swiata,2/niewyslowione-okrucienstwa-druzgocacyraport-onz-o-korei-polnocnej,355284.html (dostęp: 15.02.2017). 
aprobata. Kraje, takie jak Rosja czy Chiny, były przeciwne jej ustanowieniu, argumentując to możliwą eskalacją napięcia i przyspieszeniem prac Korei Północnej nad bronią nuklearna ${ }^{53}$. Mimo tych obiekcji komisja zbierała materiały, czego efektem jest opublikowany raport ONZ koncentrujący się na problematyce łamania praw człowieka w KRLD ${ }^{54}$. W dokumencie jednoznacznie stwierdzono, że w KRLD dochodzi do systematycznych naruszeń praw człowieka, a metody stosowane przez reżim wyczerpują znamiona zbrodni przeciwko ludzkości ${ }^{55}$. Zbrodnia ta została zdefiniowana w art. 7 Rzymskiego Statutu Międzynarodowego Trybunału Karnego, sporządzonego w Rzymie dnia 17 lipca 1998 r. (Dz. U. z 2003 r. Nr 78 poz. 708), obejmując takie czyny, jak: zabójstwo, eksterminacja, niewolnictwo, deportacja lub przymusowe przemieszczanie ludności, uwięzienie lub inne dotkliwe pozbawienie wolności fizycznej z naruszeniem podstawowych reguł prawa międzynarodowego, tortury, zgwałcenie, niewolnictwo seksualne, przymusowa prostytucja, wymuszona ciąża, przymusowa sterylizacja oraz jakiekolwiek inne formy przemocy seksualnej porównywalnej wagi, prześladowanie jakiejkolwiek możliwej do zidentyfikowania grupy lub zbiorowości z powodów politycznych, rasowych, narodowych, etnicznych, kulturowych, religijnych, płci lub z innych powodów powszechnie uznanych za niedopuszczalne na podstawie prawa międzynarodowego, wymuszone zaginięcia osób, zbrodnia apartheidu, inne nieludzkie czyny o podobnym charakterze, powodujące ogromne cierpienie lub poważne uszkodzenie ciała albo zdrowia psychicznego lub fizycznego. Zbrodnie przeciwko ludzkości polegają na świadomym, systematycznym ataku skierowanym przeciwko ludności cywilnej, dokonywanym zarówno w trakcie konfliktu zbrojnego, jak i w czasie pokoju.

Analizując powyższe rozważania dotyczące warunków panujących w północnokoreańskich obozach, należy z całą stanowczością stwierdzić, że wpisują się one w znaczenie terminu „eksterminacja” przyjętego w Rzymskim Statucie Międzynarodowego Trybunału Karnego. Eksterminacja obejmuje bowiem celowe pozbawienie dostępu do jedzenia i opieki medycznej, które są obliczone na wyniszczenie części ludności ${ }^{56}$. Jak słusznie zwraca uwage Jacek Izydorczyk, „zbrodnie przeciwko ludzkości obejmują wyłącznie najbardziej drastyczne przejawy łamania podstawowych praw człowieka, które ze względu na swoją skalę lub charakter moga w praktyce okazać się niezwykle trudne do ścigania w wewnątrzpaństwowym wy-

53 http://www.tvn24.pl/wiadomosci-ze-swiata,2/prawa-czlowieka-w-korei-polnocnej-radabezpieczenstwa-zabiera-glos,500887.html (dostęp: 15.02.2017).

54 United Nations General Assemblay Report of the commission of inquiry on human rights in the Democratic People's Republic of Korea, https://documents-dds-ny.un.org/doc/UNDOC/GEN/G14/108/66/PDF/G1410866.pdf?OpenElement (dostęp: 17.08.2017).

55 http://www.tvn24.pl/wiadomosci-ze-swiata,2/onz-udowodnil-zbrodnie-korei-szanse-naukaranie-kima-zadne,400585.html (dostęp: 15.02.2017).

56 M. Płachta, Międynarodowy Trybunał Karny, t. 2, Kraków 2004, s. 58. 
miarze sprawiedliwości, a przede wszystkim stają się przedmiotem zainteresowania społeczności międzynarodowej" ${ }^{57}$.

Można postawić pytanie, dlaczego autorzy raportu nie zdecydowali się na przypisanie przewodniczącemu Partii Pracy Korei odpowiedzialności za zbrodnię ludobójstwa. Wprawdzie w doktrynie nie ma zgody odnośnie do tego, czy zbrodnia ludobójstwa stoi na czele hierarchii zbrodni międzynarodowych ${ }^{58}$, niewattpliwie jednak niesie ona za sobą ogromny ciężar gatunkowy. Natomiast zdaniem części przedstawicieli doktryny jest najpoważniejszą ze zbrodni rangi międzynarodowej ${ }^{59}$. Należy jednak podkreślić, że udowodnienie zbrodni ludobójstwa jest bardzo skomplikowane, wymaga bowiem przypisania sprawcy tzw. zamiaru specjalnego (dolus specialis). Oskarżonemu o popełnienie zbrodni ludobójstwa trzeba przypisać świadomość planu ludobójstwa, a jak zwraca uwagę D. Dróżdż, w sytuacji, gdy oskarżony nie przyznaje się do popełnionej zbrodni, zbadanie stanu jego umysłu w momencie jej popełniania może okazać się bardzo trudne ${ }^{60}$. Zakładając nawet, że ten aspekt zostałby zrealizowany, wypada zwrócić uwagę na jeszcze jedną istotną kwestię. Otóż Konwencja w sprawie zapobiegania i karania zbrodni ludobójstwa, uchwalona przez Zgromadzenie Ogólne Narodów Zjednoczonych dnia 9 grudnia 1948 r. (Dz. U. z 1952 r. Nr 2, poz. 9), a w ślad za nią Rzymski Statut Międzynarodowego Trybunału Karnego, do chronionych przepisami konwencji zaliczaja grupy: narodową, etniczna, rasową i wyznaniową. Więźniowie odbywający swoje kary w północnokoreańskich obozach pracy nie zaliczają się do żadnej z wymienionych grup; stanowią oni swego rodzaju grupe polityczna, wymierzona przeciwko Kim Dzong Unowi i całemu aparatowi władzy. Taka grupa nie jest jednak chroniona przepisami konwencji. Już R. Lemkin - twórca definicji zbrodni ludobójstwa - sprzeciwiał się objęciu grupy politycznej przepisami konwencji z uwagi na jej labilny charakter ${ }^{61}$. Reasumując, trudności w udowodnieniu zamiaru ludobójczego, a przede wszystkim fakt pominięcia w przepisach konwencji grupy politycznej uniemożliwiają zaklasyfikowanie zbrodni popełnianych w północnokoreańskich obozach pracy jako zbrodni ludobójstwa.

Przypisanie zbrodni przeciwko ludzkości jest o wiele prostsze, nie wymaga bowiem udowodnienia dolus specialis. Zbrodnie rangi międzynarodowej powinny być ścigane przez każdą kompetentną do tego władzę, wedle ustalonych norm i zwyczajów rangi międzynarodowej. Zgodnie z treścią preambuły Rzymskiego Statutu MTK „(...) potwierdzając, iż najpoważniejsze zbrodnie wagi międzynarodowej nie

${ }_{57}$ M. Królikowski, P. Wiliński, J. Izydorczyk, Podstawy prawa karnego międżynarodowego, Warszawa 2008, s. $125,126$.

58 Więcej na ten temat: K. Wierczyńska, Hierarchia z̧brodni w prawie międzynarodowym, „Państwo i Prawo" 2016, nr 1, s. 58-72.

59 M. Królikowski, P. Wiliński, J. Izydorczyk, Podstany prawa karnego..., s. 116.

${ }^{60}$ D. Dróżdż, Zbrodnia ludobójstwa w międzynarodonym prawie karnym, Kraków 2010, s. 187.

${ }^{61}$ Ibidem, s. 165. 
moga pozostać bezkarne oraz że ich skuteczne ściganie musi zostać zapewnione poprzez podjęcie odpowiednich działań zarówno przez poszczególne państwa, jak i poprzez wzmocnienie współpracy międzynarodowej, zdecydowane by położyć kres bezkarności sprawców tych zbrodni (...); obowiązkiem każdego Państwa jest wykonywanie jurysdykcji karnej w stosunku do osób odpowiedzialnych za zbrodnie międzynarodowe". Artykuł 13 Rzymskiego Statutu MTK stanowi natomiast, że „Trybunał może wykonywać jurysdykcję zgodnie z postanowieniami statutu, jeśli z takim wnioskiem wystapi Państwo Strona, Rada Bezpieczeństwa ONZ działająca na podstawie rozdziału VII Karty Narodów Zjednoczonych lub jeśli takie postępowanie zostanie wszczęte przez Prokuratora na podstawie uzyskanej informacji o zbrodniach podlegających jurysdykcji Trybunału" ${ }^{\prime 2}$. W postępowaniu przed Międzynarodowym Trybunałem Karnym obowiązuje bowiem zasada komplementarności, według której jurysdykcja MTK właściwa jest dopiero wówczas, gdy dane państwo odmawia pociagnięcia sprawcy do odpowiedzialności bądź nie posiada ku temu instrumentów prawnych ${ }^{63}$.

Analizując ten aspekt, należy jednak zwrócić uwagę na fakt, że Korea Północna nie jest stroną Rzymskiego Statutu MTK. Nie wyklucza to jednak hipotetycznej możliwości pociagnięcia Kim Dzong Una do odpowiedzialności przed Trybunałem. Niezbędny stałby się wówczas wniosek Rady Bezpieczeństwa ONZ, który musiałby zostać jednomyślnie poparty przez jej pięciu stałych członków, a więc przez: Rosję, Chińską Republikę Ludową, Francję, Stany Zjednoczone oraz Wielką Brytanię. Sytuacja polityczna na arenie międzynarodowej jest jednak bardzo skomplikowana. Trudno sobie wyobrazić sytuację, że wniosek zostanie zaaprobowany m.in. przez Chiny, zwłaszcza że są one głównym partnerem KRLD, pomagającym $\mathrm{mu} \mathrm{w}$ przechwytywaniu uciekinierów. Warto przy tym zwrócić uwagę, że nawet w sytuacji osiagnnięcia niezbędnego konsensusu jurysdykcja Trybunału zostałaby ograniczona jedynie do czynów popełnionych po 1 lipca 2002 r., zgodnie bowiem z treścią art. 11 Rzymskiego Statutu MTK, ,jurysdykcją Trybunału objęte są wyłącznie zbrodnie popełnione po wejściu w życie (...) statutu". Mając na uwadze powyższe trudności, bardziej celowe wydaje się powołanie trybunału ad hoc, który holistycznie podszedłby do problematyki naruszeń praw człowieka w Korei Północnej. Jak pokazuje przeszłość, takie trybunały niejednokrotnie spełniły swoją funkcje $e^{64}$, a opracowane przez nie standardy na stałe przeniknęły do zasad prawa karnego międzynarodowego.

62 M. Płachta, Międzynarodowy Trybunat..., s. 68, 69.

63 M. Królikowski, P. Wiliński, J. Izydorczyk, Podstawy prawa karnego..., s. 258, 259.

${ }^{64} \mathrm{Na}$ szczególną uwagę zasługują: Międzynarodowy Trybunał Karny dla byłej Jugosławii, utworzony na mocy rezolucji 827 Rady Bezpieczeństwa ONZ z 25 maja 1993 r. w celu osądzenia osób odpowiedzialnych za poważne naruszenia międzynarodowego prawa humanitarnego popełnione na terytorium byłej Jugosławii od 1991 r., a także Międzynarodowy Trybunał Karny dla Rwandy, utworzony 8 listopada 1994 r. na mocy rezolucji nr 955 Rady Bezpieczeństwa ONZ do 
Korea Północna była wielokrotnie wzywana do wypowiedzenia się w sprawie stawianych jej oskarżeń, jednak ani razu nie skorzystała z przysługującego jej uprawnienia, oświadczając ponadto, że przedstawione dowody zostały spreparowane.

\section{Uwagi końcowe}

W KRLD nagminnie łamane są prawa człowieka. Mimo odrębności dzielących kulturę cywilizacji zachodnich i wschodnich trzeba pamiętać, że Korea Północna pozostaje sygnatariuszem wielu multilateralnych umów międzynarodowych, m.in. Międzynarodowego Paktu Praw Obywatelskich i Politycznych ${ }^{65}$, Międzynarodowego Paktu Praw Gospodarczych, Społecznych i Kulturalnych ${ }^{66}$, a także Konwencji o prawach dziecka ${ }^{67}$ czy Konwencji w sprawie likwidacji wszelkich form dyskryminacji kobiet ${ }^{68}$.

W myśl art. 10 Międzynarodowego Paktu Praw Obywatelskich i Politycznych osoby pozbawione wolności musza być traktowane w sposób humanitarny, niezależnie od statusu więźnia. Sposób obchodzenia się z nimi nie powinien być zależny od tego, czy posiadają one zdolność do „życia społecznego czy politycznego” zgodnie z zasadami ideologii dżucze ${ }^{69}$. Pomimo ujawnienia zdjęć satelitarnych obozy koncentracyjne istnieją nadal, ponieważ na trwałe wpisały się północnokoreańską odmianę socjalizmu. Mimo że formalnie na terytorium KRLD nie funkcjonuje żadna opozycja polityczna, to pojawiają się antagoniści obowiązującego systemu. Jak stwierdza H. Ogawa: „W Korei znaleźli się odważni opozycjoniści. Odwaga zaprowadziła ich wraz z całymi rodzinami do obozów" ${ }^{\prime 70}$. Bardzo celne wydaje się przy tym pytanie postawione przez J. Sweeneya: „Co jest dowodem na to, że (...) sprzeciw wobec reżimu istnieje? Ludzie w obozach koncentracyjnych"ᄁ1.

osądzenia osób odpowiedzialnych za ludobójstwo oraz inne poważne naruszenia międzynarodowego prawa humanitarnego popełnione na terytorium Rwandy oraz obywateli Rwandy odpowiedzialnych za ludobójstwo i inne tego typu poważne naruszenia popełnione na terytorium państw ościennych pomiędzy 1 stycznia a 31 grudnia $1994 \mathrm{r}$.

65 Międzynarodowy Pakt Praw Obywatelskich i Politycznych otwarty do podpisu w Nowym Jorku dnia 19 grudnia 1966 r. (Dz. U. z 1977 r. Nr 38, poz. 167).

${ }_{66}$ Międzynarodowy Pakt Praw Gospodarczych, Społecznych, Kulturalnych otwarty do podpisu w Nowym Jorku dnia 19 grudnia 1966 r. (Dz. U. z 1977 r. Nr 38, poz. 169).

${ }^{67}$ Konwencja o prawach dziecka przyjęta przez Zgromadzenie Ogólne Narodów Zjednoczonych dnia 20 listopada 1989 r. (Dz. U. z 1991 r. Nr. 120, poz. 526).

68 Konwencja w sprawie likwidacji wszelkich form dyskryminacji kobiet przyjęta przez Zgromadzenie Ogólne Narodów Zjednoczonych dnia 18 grudnia 1979 r. (Dz. U. z 1982 r. Nr 10, poz. 71).

${ }^{69}$ H. Ogawa, Pochwata..., s. 74.

70 H. Ogawa, Wspótzależność..., s. 82.

71 J. Sweeney, Korea Pótnocna..., s. 358. 
Mur milczenia zaczyna powoli pękać. Prędzej czy później gnębiona latami ludność Korei odzyska wolność, a ludzie, którzy stoją za machina śmierci i zniewolenia, zostaną pociagnięci do odpowiedzialności.

Warto podkreślić, że w dniu 21 stycznia 2016 r. Parlament Europejski przyjął rezolucje potępiająca próby jądrowe i naruszenia praw człowieka w północnej części Półwyspu Koreańskiego ${ }^{72}$. Wyraził głębokie zaniepokojenie ciagłym pogarszaniem się sytuacji w zakresie praw człowieka. Wezwał rząd KRLD do wypełnienia zobowiązań wynikających z instrumentów praw człowieka, których jest stroną, oraz do zapewnienia organizacjom humanitarnym, niezależnym obserwatorom praw człowieka i Specjalnemu Sprawozdawcy ONZ ds. Sytuacji w Zakresie Praw Człowieka w KRLD dostępu do tego kraju i niezbędnej współpracy. Wezwał rząd KRLD do natychmiastowego zaprzestania stosowania praktyk polegających na systematycznym tłumieniu praw człowieka jako narzędzia politycznego służącego kontroli i monitorowaniu własnych obywateli. Zdecydowanie potępił systematyczne i szerokie stosowanie kary śmierci. W celu ograniczenia jej wymierzania wezwał rząd Korei Północnej do ogłoszenia moratorium na wykonanie wszystkich wyroków śmierci z myśla o jej zniesieniu w najbliższej przyszłości. Ponadto zaapelował o zaprzestanie wykonywania pozasądowych egzekucji i położenie kresu wymuszonym zaginięciom, o uwolnienie więźniów politycznych oraz zezwolenie obywatelom na swobodne podróżowanie, zarówno w obrębie kraju, jak i poza jego terytorium. Wezwał rząd KRLD do rezygnacji z państwowego programu pracy przymusowej, w ramach którego zagraniczne kraje zatrudniły nielegalnie dziesiątki tysięcy północnokoreańskich pracowników, głównie w górnictwie, przy wyrębie lasów, w przemyśle tekstylnym i budownictwie. Program ten był źródłem twardej waluty, pomocnej w utrzymaniu reżimu. Parlament Europejski podkreślił ponadto, że w takim przypadku odpowiedzialność za ochronę praw pracowniczych rozszerza się na państwa przyjmujące, które powinny zapewnić ochronę norm pracy i praw człowieka. Potępił surowe ograniczenia wolności myśli, sumienia, religii i wyznania, wolności słowa i wolności wyrażania poglądów, wolności zgromadzeń i zrzeszania się, a także dyskryminację opartą na systemie songbun, który klasyfikuje ludzi według przypisywanej przez państwo klasy społecznej i urodzenia oraz bierze pod uwagę poglądy polityczne i religijne.

Parlament Europejski wyraził szczególne zaniepokojenie dramatyczną sytuacja żywnościowa panująca w Korei Północnej oraz jej wpływem na prawa gospodarcze, społeczne i kulturalne ludności; wezwał Komisję do kontynuowania istniejących programów pomocy humanitarnej oraz utrzymania istniejących kanałów komunikacji z KRLD, a także do dopilnowania, aby pomoc bezpiecznie docierała do grup ludności, do których jest skierowana. Ponadto wezwał władze KRLD do zapewnienia wszystkim obywatelom dostępu do żywności i pomocy humanitarnej w zależności

72 https://www.europarl.europa.eu/doceo/document/TA-8-2016-0024_EN.html (dostęp: 15.11.2019). 
od potrzeb i zgodnie z zasadami humanitarnymi. Podkreślił, że wspólnota międzynarodowa zdecydowanie zbyt długo bezczynnie przygląała się naruszeniom opisanym w sprawozdaniu komisji śledczej, z których wiele stanowi zbrodnie przeciwko ludzkości, jednocześnie wezwał rząd KRLD do niezwłocznego wdrożenia zaleceń komisji śledczej. Stwierdził ponadto, że nadszedł odpowiedni czas na podjęcie przez wspólnotę międzynarodową konkretnych działań kładących kres bezkarności sprawców. Parlament Europejski wyraził oczekiwanie, że osoby, na których spoczywa największa odpowiedzialność za zbrodnie przeciwko ludzkości popełnione w KRLD, odpowiedza za swoje czyny, stana przed Międzynarodowym Trybunałem Karnym i zostana objęte ukierunkowanymi sankcjami. Mimo że rezolucja Parlamentu Europejskiego nie ma charakteru prawnie wiążącego, to stanowi bardzo ważny krok w dyskusji nad sytuacją w Korei Północnej. Trzeba przy tym pamiętać, że w sprawie zbrodni popełnionych na terytorium byłej Jugosławii Organizacja Narodów Zjednoczonych również zaczynała od podejmowania rezolucji ${ }^{73}$, które stały się podstawą do zapoczątkowania działań mających na celu powołanie Międzynarodowego Trybunału do osądzenia osób odpowiedzialnych za poważne naruszenia międzynarodowego prawa humanitarnego popełnione na terytorium byłej Jugosławii od $1991 \mathrm{r}^{74}$

\section{SUMMARY}

\section{HUMAN RIGHTS VIOLATIONS \\ IN THE DEMOCRATIC PEOPLE'S REPUBLIC OF KOREA}

This article is an attempt to show the problem of the violation of human rights in the communist Democratic People's Republic of Korea, based on the example of forced labour camps functioning there. North Korea is a country in which there is no political opposition, as all forms of disobedience to the existing dictatorship are severely punished. The regime uses terror in the form of capital punishment or labour camps to maintain control over society. These camps markedly resemble the concentration camps that existed in Europe during the Second World War. The methods used there are crimes against humanity. Torture, human experiments and complete disregard for human life occur there on level that is very similar to methods employed by the Nazis in their death camps. Public opinion has long tried not to perceive the problem and to maintain a wall of silence. However on the international stage, this wall is beginning to crumble. More and more voices can be heard calling for international intervention and prosecution of perpetrators for responsibility for crimes before a competent international body.

73 W dniu 6 października 1992 r. Rada Bezpieczeństwa ONZ wydała rezolucję nr 780 o utworzeniu Komisji Ekspertów dla zbierania informacji mających na celu dostarczenie Sekretarzowi Generalnemu informacji na temat przestrzegania konwencji genewskich na terytorium byłej Jugosławii.

74 Powołany do życia przez Radę Bezpieczeństwa ONZ na mocy rezolucji 827 z dnia 25 maja $1993 \mathrm{r}$. 